\title{
Albinism in the Ancient Mediterranean World
}

\author{
John L. Hilton \\ jlhilton@webafrica.org.za
}

\section{Abstract}

The discovery of DNA in the $20^{\text {th }}$ century and recent biomedical research into the human genome in Southern Africa have shed much light on the diagnostic, epidemiological, and sociological aspects of albinism. Less attention has been given to the historical evidence for the condition and its religious context, especially in the ancient Mediterranean World. This article assembles the meagre evidence for albinism in antiquity and investigates to what extent it was treated as 'sacred'.

Keywords: Ancient Mediterranean, albinism, the sacred, conception, sacrifice, astral cults

\section{Introduction}

Recent biomedical studies in Southern Africa have made considerable progress in explaining the genetic aetiology of albinism ${ }^{1}$ (Kromberg 2018a:38-48). The condition takes on many forms throughout nature and is very distinctive in humans as a result of the absence or reduced levels of melanin in the skin, hair, and eyes. In the case of ocular albinism, the condition may affect only the eyes, while the hair and skin have pigmentation

According to Kromberg (2018c:3), 'the genetics of albinism is complex and... there is genetic locus heterogeneity' (cf. also Spritz 2013). The entire book of Kromberg and Manga (2018) provides comprehensive coverage of the various forms of albinism in Africa (where this condition occurs most noticeably) and its distribution. For an earlier systematic treatment, including references to albinism in antiquity (but not including Julian), see Pearson, Nettleship, and Usher (19111913). 


\section{John L. Hilton}

in varying degrees, the levels increasing with age (Lewis 2015; Kirkwood 2009). The mode of transmission varies: Ocular albinism is X-linked, meaning that it is transmitted by a female carrier, while the full oculocutaneous variety is handed on in an autosomal recessive manner from both parents.

In terms of the epidemiology of the condition, it is approximately four to five times more prevalent in Africa than it is in Europe (Kromberg 2018a:58-59). It is also much more conspicuous in Africa, since individuals who lack pigmentation stand out markedly from other black Africans. In some communities in the rest of the world the incidence is much higher. Among the Cuna Indians of Panama, for example, the rate was reported in the 1960 s to be 1:200 as opposed to 1:20,000 in Europe (Keeler 1964:115-118). Among the Hopi Indians of North America, the figure was 1:227 (Woolf \& Grant 1962:393, 399). Today, albinism is strongly present all over Southern Africa and encounters with those affected are very common (Kromberg 2018a:72-76).

Explanations vary for the higher prevalence of albinism in these communities and in Africa, despite the obvious disadvantages that are associated with the condition, such as the development of skin cancers and impaired vision as a result of exposure to bright sunlight. According to some studies, albinos were historically viewed as 'sacred' beings and lived a life of relative ease, making intermarriage with them advantageous, while others conversely note a preference for consanguineous unions as a result of social exclusion, or a sustained diachronic preference for lighter skins ${ }^{2}$ (Kromberg 2018b:8; cf. Kromberg 1987; Ardener 1954).

From a historical perspective, albinism has been viewed ambivalently - it is sometimes thought to be connected with the divine, while at other times it is considered queer, monstrous, and ill-omened ${ }^{3}$ (Imafidon 2019:28-

2 The use of the term 'sacred' is a controversial term in the study of religions and will be discussed at greater length below. I am grateful to the editor of JSR for pointing this out to me. According to accounts cited by Pearson et al. (19111913:13), they were viewed as prodigies, from whom other Africans fled in fear.

3 More recent studies of albinism, for example Clarke and Beale (2018), stress the social aspects of the condition, while earlier accounts, notably De Heusch (1985), provide mythological narratives which attempt to explain it in religious terms. Yet even today, the belief in the magic power of albino body parts persists and is the main reason why they are often murdered in Africa for muti. 
51; Clarke \& Beale 2018:257-270; Brocco 2016; Baker 2010; De Heusch 1985:125-160). History has not been kind to those with the condition: In the past, they might have been thought to have a connection with the sun, the moon, or the stars, and treated with respect. Today they are largely shunned, stigmatized, or even hunted down for the purpose of making muti in witchcraft, notably in the mining areas of Tanzania ${ }^{4}$ (Kromberg 2018c:191-194, 196-197). Those affected are sometimes held to belong both to the world of the dead and the living and to have an intermediate status between the two that gives them 'magical' power". The condition has prompted many myths in traditional societies, especially in respect of the causes of the condition, which involve, among other things, allegations of sorcery and the theory of maternal impression (see further below) (Kromberg 1992; Baker 2010).

Today, a clinical diagnosis of albinism can be made on the basis of a scientific analysis of the skin of patients or by means of genetic profiling (Kerr \& Kromberg 2018:236). These methods are, of course, not at the disposal of the ancient historian. Instead, an analysis of descriptions of the physical appearance of the subjects (often expressed in religious, symbolic, or metaphorical terms) must be undertaken, together with an observation of their physical behaviors, such as the involuntary movements characteristic of nystagmus, and evidence from the subject's family history. Such assessments are inevitably difficult to make with absolute certainty. There is also a number of factors that make the problem worse: The ancient evidence is often literary rather than scientific ${ }^{6}$, while surviving accounts often derive from travelers' tales of people with strange eyes in remote locations, and are frequently sketchy, fragmentary, and vague. Albinism was often viewed with hostility or fear in ancient societies, so that surviving descriptions are

4 With regards to the change in attitudes for the worse, Kromberg (2018c:192) relates that 'the younger Hopi Indians who learned the condition was a genetic defect might show discrimination, whereas the older traditional people showed only positive attitudes'. For the use of albino fetishes to aid miners in Tanzania, see Bryceson, Jønsson, and Sherrington (2010).

5 The term 'magic' is also much debated, of course (cf. Mauss 1972; Dickie 2001; Graf 2002).

6 There are explorations of albinism in modern literature such as the Australian writer, David Malouf (1993), and the Hungarian György Sebestyén (1993), while in French literature the work of Didier Destremau, Patrick Grainville, and Williams Sassine focus on this theme. For these French writers, see Baker (2011). 


\section{John L. Hilton}

frequently distorted, obscured, and expressed in circumlocutions, even by those who had the condition, and finally, a diagnosis of medical diseases and conditions in antiquity is notoriously difficult, even when symptoms are observed accurately and in great detail ${ }^{7}$. These factors need to be emphasized very strongly at the outset of this essay and allowance needs to be made for the lack of precision in assessing the ancient evidence. However, since the condition is found universally in nature, when allowance is made for the prescientific nature of many of the descriptions of albinism that survive from antiquity, and when the cumulative weight of such descriptions is weighed up, the probability is that the phenomenon of albinism does indeed underlie many of these accounts.

This article has a twofold aim: To discuss the available evidence for albinism in the ancient Mediterranean world and to assess to what extent the condition was held to be 'sacred" ${ }^{\text {. }}$

\section{Albinism in Nature}

The account given above provides a brief summary of how albinism is understood in terms of contemporary science. It reflects the massive shift in understanding such medical conditions that have come about after the discovery of DNA by scientists in the $19^{\text {th }}$ and $20^{\text {th }}$ centuries (Olby 1994) ${ }^{9}$. However, even prior to these discoveries, the unusually pale appearance of many animals and humans was remarked on. Preeminent among literary accounts is Herman Melville's Moby Dick (Melville 1851), which narrates the story of Captain Ahab's obsessive hunting of an albino whale. In Chapter 42 of this $19^{\text {th }}$-century novel, written before the advent of modern genetics, the narrator, Ishmael, invokes the complex associations of legendary albino creatures: The white elephants of Siam (cf. the elephans albus of Horace Ep. 2.1.196; Fairclough [1926] 1966:412-413), the white steed of the plains in

7 See, for example, the many theories concerning the plague at Athens in 429 BCE: Papagrigo-rakis (2006, on typhoid), Morens and Littman (1992, on respiratory illness), Hopper (1992, on Lana fever), Littman and Littman (1969, on smallpox), and Eby and Evjen (1962, on glanders).

8 See also the discussion of the term 'sacred' below.

9 For the importance of wonders, monsters, and other oddities for modern science, see Daston and Park (1998:173-214). 
North America (Melville 1851:210), the pale horse (i $\pi \pi \circ \varsigma \chi \lambda \omega \rho$ ós) of the apocalypse ( $\operatorname{Rev} 6.8)$, the tale of the tall pale man of the Hartz forest in central Europe (Melville 1851:214), and the whiteness of the polar bear and some tropical sharks (Melville 1851:209). Literary perspectives such as these are important testimonies to the complexity of albinism and the impact that it makes on our conception of what it is to be human from the perspective of biology.

There are many indications of albinism in the natural history of the ancient world, particularly in the animal kingdom. For example, in his Life of Sertorius 11.4, Plutarch tells the story of how a man who was living in the country presented Sertorius with an unusual doe, which he presented to the general to gain his favor. He was surprized by the strange color of its skin

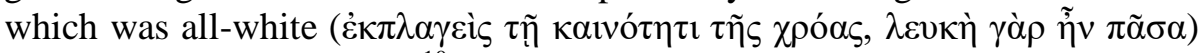
(Perrin [1919] 1968:28-29) ${ }^{10}$. Sertorius was at first not overly impressed with this gift, but over time he came to give the animal a religious importance and

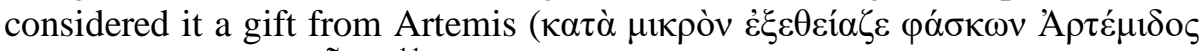

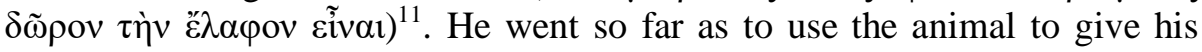
military decisions and victories a religious authority - one presumes that this was widely accepted by his followers. This anecdote may be connected with the white hart or hind of the medieval legend (Graves 1948:340).

\section{Albinism in the Ancient Mediterranean Region}

Albinism does not feature overtly in the surviving texts from the ancient world or in the scholarship about it ${ }^{12}$. The term itself was only invented in modern languages by the Spanish explorer, De Argensola in 1609 in his

10 On paradoxography in the life of Sertorius, see Moreno (1992). The text and translation of the Life of Sertorius can be found in Perrin ([1919] 1968).

11 'Within a short time, he deified the doe saying that it was the gift of Artemis'.

12 Snowden $(1970 ; 1983)$ does not use the term. There is only a passing mention of albinos in Papua New Guinea in Garland (2010:2-3). There is no entry in any of the editions of the Oxford Classical Dictionary (Hornblower, Spawforth, \& Eidinow 2012) including the new online version, nor is the condition discussed in Brill's new Pauly (Cancik, Schneider, Salazar, \& Orton 2002), apart from a passing reference of a possible albino sparrow in Aristotle HA 3.12.519a.5-19 (discussed below). 


\section{John L. Hilton}

account of Molucca and the Philippines, although it may ultimately go back as far as Pliny's description of albinos in Albania ${ }^{13}$.

\section{Noah}

The apocryphal Book of Enoch, which is a canonical text in Christian Ethiopia, was written in the $2^{\text {nd }}$ or $1^{\text {st }}$ century BCE and survived only in the Ge'ez language, together with some Aramaic fragments from the Qumran scrolls (Knibb \& Ullendorff 1978; Schürer, Vermes, Millar, \& Goodman 1986:250-268; Charlesworth 1983-1985). Appended to it is a short account of the birth of Noah, relating how the wife of Enoch's grandson, Lamech, gave birth to a child whose

body was white as snow and red as a rose; the hair of his head white as wool and the demdema beautiful; and as for his eyes, when he opened them the whole house glowed like the sun - (rather) the whole house glowed even more exceedingly (The Book of Enoch 106; Charlesworth 1983-1985:86) ${ }^{14}$.

Lamech then went to his father, Methuselah and informed him that his wife had given birth to a son who was different from normal babies and who resembled 'the sons of the God of Heaven' (Charlesworth 1983-1985:86). Lamech told his father that he suspected that the conception had occurred through the intervention of 'the angels of heaven'15 (Charlesworth 19831985:87), since the infant was not like ordinary mortals in that his eyes were

13 For a discussion on the first scientific dialogs of albinism, see Little (1995:23-46) and Andree (1889:238-260). The Oxford English Dictionary (Simpson \& Weiner 1989) dates the first Spanish use of the term to 1609 in the treatise of De Argensola (1708) on the recent discoveries in Molucca and the Philippine islands. However, earlier references to 'Albians', or 'Albanes' may ultimately derive from Pliny's account of albinos in Albania (cf. below and Froggatt 1960). See also the explicit derivation of albani from albus (white) in Julius Solinus 15.5 discussed below.

14 See Sorsby (1974:17-18, 256). Noah was considered to be spiritually pure and a mediator between divine wrath and human corruption (Gen 5.28-29), perhaps as a consequence of his albinism.

15 This detail, and others in the narrative, are preserved in the Aramaic Genesis Apocryphon (cf. Avigad \& Yadin 1956; Vermes 2004:481). 
like the rays of the sun, and his face was glorious. Methuselah in turn went to Enoch to tell him the news, adding that Lamech did not believe that the newborn child was his. Enoch told Methuselah that this prodigious birth was the result of the transgressions of the angels of heaven who had lain with human women and had produced offspring from them. He added that this sinfulness would result in great punishment on earth, a deluge, and the destruction lasting for a year to purify the earth of these transgressions. However, the newborn infant, who was truly Lamech's $\operatorname{son}^{16}$, would be called Noah and would survive the flood together with his sons.

This narrative contains many of the elements that characterize later accounts of the birth of albinos: The strikingly unusual and even alien appearance of the newborn child, especially the pale body with a reddish tinge, the strange hair and the beautiful eyes, the suspicions of adultery, illegitimacy, his divine conception, the connection with the sun, and the belief in the connection with the divine powers ${ }^{17}$.

\section{Greek and Roman Paradoxography: Albania}

Albinos feature among the wonders of antiquity. Pliny (HN 7.12), for example, reports about the statement of Isigonus of Nicaea that 'people are born in Albania who have greyish eyes, are white from boyhood, and who see better at night than during the day ${ }^{18}$. Little is known about Isigonus other than that he was a paradoxographer (a collector of information about the wondrous and strange beings in remote parts of the world) who lived and worked in the $1^{\text {st }}$ century BCE or the $1^{\text {st }}$ century CE (Geus \& King 2018:432436). The interest in paradoxography developed in Hellenistic literature after the conquest of the Persian empire by Alexander the Great (Geus \& King 2018). Collections of marvels appeared in the $3^{\text {rd }}$ century BCE among the writings of Aristotle, Callimachus, and other Hellenistic writers, and continued to be popular in the $2^{\text {nd }}$ century $\mathrm{CE}$ when notable collections were produc-

16 This part of the narrative is preserved on fragment 4Q204 from Qumran (cf. Milik 1976:178-184; Vermes 2004:546-547).

17 Similar accounts are given of albinism in the Iranian tradition, see Krappe (1944).

18 Idem [i.e. Isigonus of Nicaea] in Albania gigni quosdam glauca oculorum acie, $e$ pueritia statim canos, qui noctu plusquam interdiu cernant. The text and translation are found in Rackham, Jones, and Eichholz (1938:514-515). Albania is a region in the Caucasus region, near modern Chechnya. 


\section{John L. Hilton}

ed by writers such as Phlegon of Tralles (Hansen 1996). Paradoxographers related information that they considered strange but true and they were generally eager to establish the credibility of the information which they related (Geus \& King 2018:434). Studies of paradoxography in the $20^{\text {th }}$ century aim to explain the 'wonders' related by these authors in rational terms (Rommel 1923; Giannini 1963; 1964).

In the $2^{\text {nd }}$ century $\mathrm{CE}$, Aulus Gellius states that he came across the works of Aristeas of Proconnesus, Isigonus of Nicaea, Ctesias, Onesicritus, Philostephanus, and Hegesias in a bookshop in Brundisium (NA 9.4) ${ }^{19}$, and he remarks particularly on the observation that in Albania the hair of some children turns white in childhood, and that they see better at night than during the day (NA 9.4.6) ${ }^{20}$ (Rolfe 1927:164-165). He claims to have run out of patience with such accounts, but nevertheless adds to the collection of anecdotes about transexuals that he gleaned from a study of Pliny's Natural History (9.4.13-14). Here he notes that Pliny had personally known about or had seen these stories, and so he argues that the information contained within it had to be treated with respect ${ }^{21}$.

Julius Solinus adds to the discussion in the $3^{\text {rd }}$ century CE (15.5). He remarks that the Albanians believed that they were the descendants of Jason $^{22}$, who had visited the region on his travels in the Argo and notes that

19 Bolton (1962:27-31) provides an analysis of the passages in Pliny $H N$ and Aulus Gellius, concluding that the source of the later paradoxographers was not Aristeas but a number of authors that made a compilation in the form of the Mirabilia of Apollonius.

$20[P]$ raeterea traditum esse memoratumque in ultima quadam terra, quae 'Albania' dicitur, gigni homines, qui in pueritia canescant et plus cernant oculis per noctem quam interdiu ('Moreover it is recorded and related that in a far-distant land called "Albania", there are some people who go white in childhood and see more with their eyes by night than they do during the day') (Rolfe 1927:164-165).

21 The account of Isigonus is accepted as a description of albinism by Kromberg (2018b:4) as well as Pearson et al. (1911-1913:12).

22 At Albani in ora agentes, qui posteros se Iasonis credi volunt, albo crine nascuntur, canitiem habent auspicium capillorum: ergo capitis color genti nomen dedit. glauca oculis inest pupula: ideo nocte plus quam die cernunt. 'But the Albanians who wish it to be believed that they are the descendants of Jason, are born with white hair (and the whiteness of their hair is an omen for them), and see better at night than by day' (Mommsen [1895] 1958:83). 
these people are born with white hair and that they consider whiteness of hair to be an omen (auspicium) (Mommsen [1895] 1958:83). He adds that the color of their heads gave the people their name (Albani as if from albus [white]) and that the blueish color of their eyes enabled them to see at night better than in the day.

\section{India}

Pliny (HN 7.12) also quotes Ctesias of Cnidus who refers to certain Indian tribes where mothers only have one child and that their children immediately turn white ${ }^{23}$. Ctesias was a medical doctor who lived in the $5^{\text {th }}$ century BCE. For some time, he lived in the court of the Persian king, Artaxerxes II and wrote a history of Persia and an account of India, from which this statement must have been taken (Bigwood 1989:302; cf. Lenfant 2004). His statement that such mothers only give birth once, might reflect the trauma caused by such events to those involved, especially the mother, resulting in a reluctance to have more children. As the case of Noah shows, the birth of an albino child was and is disturbing (Kromberg, Zwane, \& Jenkins 1987; Kromberg 2018c:173-176), and there is some evidence that fertility rates among albinos might be affected (Kromberg 2018a:73).

Lucian (Prom es 4) describes the mixed reactions of an Alexandrian crowd to the display of a man with partial albinism by Ptolemy I (366-282). Lucian writes that this was 'a man of two colours, half jet black and half dazzlingly white, the colours equally divided ${ }^{24}$. Similarly, Philostratus (VA 3.3) relates that Apollonius had seen a woman in India whose body was a mixture of black and white, adding that, in India such women are devoted to Aphrodite and are bred to serve the goddess, as Apis was in Egypt ${ }^{25}$.

23 Ctesias scribit...in quadam gente Indiae feminas semel in vita parere genitosque confestim canescere. 'Ctesias writes that in a certain tribe in India women give birth once in their lives and that their offspring immediately go white' (Rackham et al. 1938:514-515).

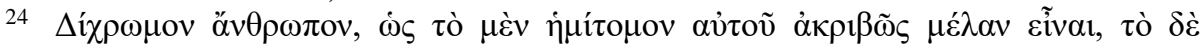

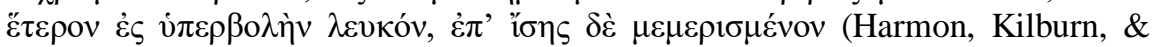
Macleod 1961:422-423; cf. also Rommel 1923:30).

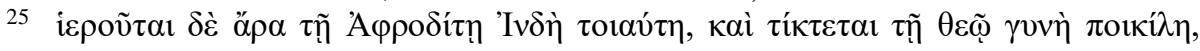

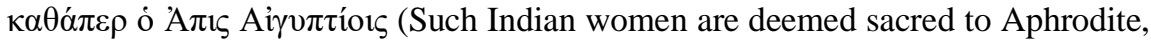
and a partly coloured woman is born for the god, like the Apis [bull] for the Egyptians') (Jones 2005:236-237; Kerényi [1927] 1962:257). Kerényi ([1927] 


\section{John L. Hilton}

Moreover, the astrologer, Vettius Valens (Ant 1.2; Kroll [1908] 1973:5) clearly attributes white spots and skin blemishes to the agency of the sun and moon ("the ram is a two-coloured sign, since the Sun and the Moon make white spots and blemishes'), which may or may not be a reference to partial albinism, or the bichromatic, patchy appearance of the skin, which features commonly in cases of albinism.

\section{Africa}

Pomponius Mela (Geog 1.23) refers to 'white Ethiopians' (Leucaethiopes) near the Nile (Romer 1998:40) ${ }^{26}$, while Agathemerus (Geog 2.5) locates them to the west of Egypt, and Ptolemy (Geog 4.6.17) situates them 'at the foot of Mt. Ryssadius' on the west coast of equatorial Africa ${ }^{27}$. Finally, Pliny ( $H N$ 5.8.43) states that they lived 'in the interior of Africa near the equator beyond the Gaetulians and the deserts' ${ }^{28}$. Unfortunately, these sources provide no further information on the subject other than their location, but it is generally accepted that these 'strange but true' accounts, referred to above, do indeed refer to cases of albinism ${ }^{29}$.

1962:256-259) argues in connection with the Aethiopica of Heliodorus, that Hydaspes' later doubts concerning the legitimacy of his daughter (VA 10.13) and the striking parallel between the black mark on Charikleia's arm (VA 10.15) and the hair on Homer's thigh (indicating his illegitimate birth) show that she was of divine birth and resembled Isis in being bichromatic.

26 At super ea quae Libyco mari abluuntur, Libyes Aegypti sunt, et Leucoaethiopes, et natio frequens multiplexque Gaetuli. 'But beyond those regions which are washed by the Libyan Sea are the Libyan Ethiopians, and the White Ethiopians, and the populous and varied nation of the Gaetulians'.

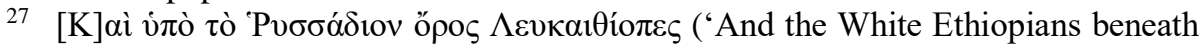
Mt. Russadius') (Nobbe \& Diller [1843-1845] 1966:270). On the white Ethiopians, see Little (1995:23-25). The term $\Lambda \varepsilon v \kappa \alpha 1 \theta i o \pi \varepsilon \varsigma$ is very rare in Greek and does not have an entry in Liddel and Scott (1968) or its supplement.

28 Interiori autem ambitu Africae ad meridiem versus superque Gaetulos, intervenientibus desertis, primi omnium Libyaegyptii, deinde Leucaethiopes habitant. 'The Libyan Egyptians and then the White Ethiopians dwell in the inner region of Africa towards the equator and beyond the Gaetulians, after the intervening deserts' (Rackham et al. 1938:548-549).

29 See, for example, Little (1995:20): L'antiquité connaissait déjà les Nègres albinos; c'est du moins ce que laisse supposer le terme de 'Leucoéthiopes' que l'on retrouve chez Pline, Pomponius Mela, Agathemenos, Ptolémée et d'autres. 


\section{Albinos as a Category of 'the Sacred' in Anthropology}

The evidence quoted and cited above shows that the phenomenon of albinism was known in the ancient Mediterranean world, although the term for it had not yet been invented. What follows below, is the second part of the essay, which aimes to assess the extent to which albinism was considered 'sacred' during this period.

The idea of 'the sacred' is a central concept in the study of religion. A key distinction has been drawn between substantive and functional definitions of the term: The first is represented in scholarship by the works of Berger (1974), Otto (1917), Van der Leeuw (1986), Eliade (1992), and Rennie (2006), and the second by Durkheim (1915) and Malinowski (1948), to name a few. While substantive definitions of 'the sacred' are transcendent or immanent, functional ones view it as a social concept ${ }^{30}$. In Greek religion,

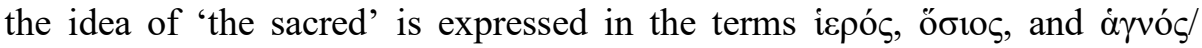
örios: These terms are defined by Burkert (1985:269-271) as follows: iøpós refers to 'that which belongs to a god or sanctuary in an irrevocable way', ő $\sigma 10 \zeta$ is 'understood from its contrast with hieros' or that which is permitted to humans, while $\dot{\alpha} \gamma v$ ó $/$ ó $\gamma 10 \zeta$ refers to 'sacred-pure', being the opposite of 'polluted'. These terms evidently differentiate between the domains of the sacred and the profane, of gods and humans, in ways that are more easily understood in terms of the functional definition of 'the sacred' than the substantive one.

This is even more apparent in Roman religion, in which - if we are to accept the statement of Aelius Gallus, a scholar of the $1^{\text {st }}$ century BCE, whose words survived in a $2^{\text {nd }}$-century summary of the work of Verrius Flaccus entitled On the meaning of words by Sextus Pompeius Festus - the term sacer (sacred) was appropriated by the state (Pirie \& Lindsay 1930:318-

On les aurait vus au sud des déserts d'Égypte et de Libye, ou encore du côté de la Gétulie (c'est-à-dire à l'intérieur de l'Algérie actuelle), entre les pays des Troglodytes et le Nil ("Antiquity knew of Black albinos - that is at least what is suggested by the term "White Ethiopians" which one finds in Pliny, Pomponius Mela, Agathemenos, Ptolemy, and the others. One would have seen them to the south of the deserts of Egypt and Libya, or again on the border of Gaetulia [that is to say in the interior of the Algeria of today], between the country of the Troglodytes and the Nile').

30 See, for example, Mauss (1972:11), stating that 'the idea of the sacred is a social idea, that is, it is a product of collective activities'. 


\section{John L. Hilton}

321). According to this text, Aelius Gallus stated that the term 'sacred' refers to anything that 'has been consecrated by the customs or institutions of the state' (Gallus Aelius ait sacrum esse quodcumque more atque instituto civitatis consecratum sit), whether it be a person condemned for wrongdoing, or a thing, except that he maintained that private obligations required by the 'institutions' of priests, such as sacrifices, are also 'sacred' (Pirie \& Lindsay 1930:318-321). According to this account (and later Roman law), a person condemned for wrongdoing is a 'sacred person' (homo sacer), who can be killed with impunity, but not sacrificed, which was taboo (nefas, as confirmed by Macrobius Sat 3.7.3) ${ }^{31}$. As pointed out by Warde Fowler, the status of the homo sacer was ambiguous (he 'was cursed and consecrated at the same moment') and the understanding of what exactly this means, developed over an extended period of time: At first, such as person was taboo, later this status was determined by the Roman priests, and later, still under the Roman Republic, it was a matter for a judicial trial (Warde Fowler 1911:58-62).

Thus, in ancient Greek and Roman society, the concept of 'the sacred' is a complex one and in all probability changed considerably over time. As I will argue below, the status of albinos belonged somewhere in the range of categories covered by the term 'sacred', and attitudes towards them varied as knowledge about them increased. It is certainly the case that those affected by albinism were widely considered in many societies to be 'sacred' in a loose sense: Kromberg and Jenkins (1984:104) report that in the South African Black society, a significant majority of the population believe that albinos are a 'gift from God', that they die in mysterious circumstances, and that they are consequently 'special'. Woolf and Grant report 'rumours' that Hopi Indians may have believed that albinism is a religious phenomenon but no longer do so (Woolf \& Grant 1962:391) ${ }^{32}$. Pearson et al. (1911-1913) cite evidence for the religious role that was played by albinos in Africa and among the Maori (who called them Korako - mythical white-skinned devils), and note that albinos in Africa belonged to a religious cult known as the

31 On the term homo sacer, see the discussion of the relationship between the individual and the state in respect of 'the sacred' in Agamben (1998).

32 Woolf and Grant (1962:391) report about 'rumours...that Hopi Indians attach some religious significance to albinism', but then add that 'present day Hopis attach no religious significance to albinos' (Woolf \& Grant 1962:393). 
Nolembo (Pearson et al. 1911-1913:61, 108, 137, 138, 141; cf. Kromberg \& Jenkins 1984:103-104, 106).

These testimonies concerning albinism in anthropology suggest that the notion that it was a 'sacred' condition, arose from general social perceptions that those with the condition were markedly different in some inexplicable way, especially with regard to their family lineage. Such at least was the case in Plutarch's story of Sertorius' white doe (Sert 11), in which the general may have exploited the superstitions of his soldiers by suggesting that the animal was sent by Artemis in order to strengthen his own authority, and in the account of Noah's birth, in which, in order to explain the unusual appearance of the newborn child, his conception was taken to be the result of intercourse between a supernatural being and Noah's mother.

The 'sacred' character of albinos in early human societies manifests itself in three main areas: Accounts of their unusual conception and birth, mythological narratives concerning the sacrifice of individuals who may be identified as albinos, and the connection between such individuals and astral bodies such as the sun, moon, and stars.

\section{Accounts of the Unusual Conception and Birth of Albinos}

The account of the birth of Noah given above, illustrates how the birth of albino children was sometimes taken as evidence of adultery on the part of the mother (Lamech did not believe that Noah was his son and suspected that his wife had had intercourse with a divine being). In some cases, suspicion of adultery led to the child who was born with albinism being exposed ${ }^{33}$ (cf. Hilton 1998b; 1998a). Occasionally, however, the strange birth was put down to a visual impression made on the mother at the time of conception (the socalled theory of 'maternal impression' in which, what the mother sees during intercourse is physically imprinted on the foetus) (Reeve 1989; Hilton 1998b; 1998a). This belief is also known from the complex story in Genesis 30.25-43 concerning the deception of Laban by Jacob, who caused the female goats and sheep of Laban to produce brindled offspring by making them look on mottled sticks in the water troughs when the males were on heat. Among the San Blas Indians there was a belief that an albino child would be conceived

33 This was the case in Heliodorus' Aethiopica 4.8, for example. 


\section{John L. Hilton}

when the mother conceives after looking on the moon during intercourse ${ }^{34}$ (Stout 1946:489; Pearson et al. 1911-1913; Keeler 1964:115-118). The Bambara in Mali thought that an albino child is conceived as a result of sexual intercourse at noon when the sun is at its strongest:

The midday sky, when the sun is at its zenith and the sky almost bright white in color, is called the sky of Faro's anger. Sexual intercourse at this time of day is a prohibition among those who adhere to Bamanaya, and Bamana and Maninka believe it results in the conception of an albino (Imperato \& Imperato 2008:46).

This is in essence the same theory that is advanced in Heliodorus (Aeth 4.8) to explain the miraculous conception and birth of a white princess, Charicleia, to black parents in that novel. According to the Ethiopian queen, Persinna, her daughter was conceived when her husband, Hydaspes, lay with her 'at noon on a summer day' after receiving a dream ordering him to do so. The queen immediately knew that she had conceived a child and when her daughter was born white, although both she and her husband were black, she feared that she would be accused of adultery and had the child exposed. The queen knew that she had not committed adultery and explained the strange color of her child on the ground that she had been looking at a painting of Andromeda, who had also been a white princess in Ethiopia, when conception had occurred. Later, when Charicleia returned to Ethiopia at the conclusion of the novel, the queen produced the painting, and the assembled crowd recognized her daughter's likeness to the mythical princess from it $(\text { Aeth } 10.14)^{35}$.

These narratives all point to the intervention of divine beings in the conception of human beings and show that (in our terms) albinism was regarded as a supernatural phenomenon.

34 See also Wafer (1934:82), referring to Wafer who goes on to say that albinos came to be white 'through the force of the Mother's Imagination, looking on the Moon at the time of Conception'.

35 For a fuller discussion of this key passage in the Aethiopica, see Hilton (1998b). 


\section{Albinism in the Ancient Mediterranean World}

\section{The Sacrifice of Albinos}

The Dogon creation myth from Nigeria explains the custom of sacrificing and eating an albino three years after the inauguration of a hogon or sacred chief, as an act of purification (De Heusch 1985:156). De Heusch suggests that the albino represents the substitute for the hogon himself ${ }^{36}$. The fullest account of the sacrifice of an albino in Greek literature is to be found in the Greek myth of Andromeda, which relates how a white Ethiopian princess, the daughter of the Ethiopian king, Cepheus, was exposed on a rock near the sea because her mother, Cassiopeia ${ }^{37}$ had proclaimed herself to be more beautiful than the Nereids $^{38}$ (Apollodorus Lib 2.4.3; Hard 1997:66). Angered by this boast, Poseidon had then flooded the land. The Ethiopians consulted the oracle of Ammon in Egypt which ruled that the anger of the god could only be appeased by the sacrifice of the king's daughter. So they chained Andromeda to a rock on the seashore to await the arrival of the sea-monster. As it happened, Perseus was flying over Ethiopia after his decapitation of Medusa. He saw the princess and immediately fell in love with her, whereupon he killed the sea-monster with his falx (a combination of a sickle and a sword) and so rescued the princess, whom he later married. Their son, Perses, was deemed to have been the ancestor of the Persian kings. Andromeda, Perseus, Cepheus, Cassiopeia, and the monster, Cetus, were all turned into constellations on their deaths ${ }^{39}$ (Hyginus Astron 2.9-12; Bunte 1875:45-46). The

36 This rite recalls the central argument of Frazer ([1890] (2009) that in early societies kings were the incarnation of the 'dying god'.

37 In terms of etymology, Cassiopeia would mean 'tin-faced woman' from $\kappa \alpha \sigma \sigma^{i} \tau \varepsilon \rho о \varsigma=$ tin $+\not ้ \psi=$ face. Since tin is a white metal, it is suggestive of albinism. The queen is sometimes called Cassiepeia, perhaps because Cassiopeia was not well understood.

38 That Poseidon's anger was the result of Cassiopeia's claim to be more beautiful than the Nereids was a later rationalization of the myth.

39 For general accounts of the myth in the ancient sources, see, in approximate order of date: Eratosthenes ( $3^{\text {rd }}$ century BCE) Cataster 15, 16, 17, 36; Anth Pal 16.147 (Antiphilus $-1^{\text {st }}$ century CE); Ovid (Met $4.668-705-1^{\text {st }}$ century CE); Conon $\left(1^{\text {st }}\right.$ century CE) Narr 40 (a rationalization of the myth); Josephus BJ 3.420 (chains of Andromeda at Joppa - $1^{\text {st }}$ century CE); Hyginus Fab 64 (Andromeda); Hyginus Poet Astr 2.9-12 (the constellations of Cepheus, Cassiopeia, Andromeda, and Perseus); Apollodorus Bib 2.4.3 ( (1t $^{\text {st }}$ or $2^{\text {nd }}$ century CE - Libanius Progymn 2.35, 


\section{John L. Hilton}

myth clearly identifies Andromeda as a princess who was white among black

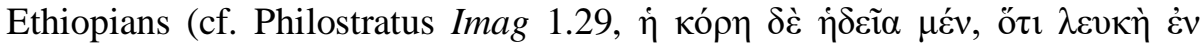
Aïrotía (The girl was pleasing inasmuch as she was white in Ethiopia) (Fairbanks 1960:116-117). Andromeda is also shown as markedly white among black Ethiopians on Attic vase paintings ${ }^{40}$ (Hilton 1998a).

\section{Albinism and the Cult of the Moon and Stars}

Anthropological literature contains many instances in which the phenomenon of albinism relates to the influence of astral bodies such as the sun, moon, and stars. In the Nigerian myth mentioned above, the albino represents Nommo, after he had been 'burnt on contact with the sun during his descent to earth' (De Heusch 1985:156). The practice of sacrificing an albino was also followed by the Bambara in Mali, during the enthronement of the kings of Segu. Here too there is a close association with the sun and a direct connection with the creating deity, Faro. The San Blas albinos were credited with the ability 'to scare away with a small bow and arrow, the demon devouring the sun or moon at times of eclipses' and refer to them with the term ibe (sun) (Stout 1946:489). The albinos of Amboina were viewed as the children of the morning star and among the Malays they were thought to be the children of the sun. Sometimes, albinism is connected with lunar influence, since albinos prefer pale light over bright light. Lionel (cf. Wafer 1934:81) records an account of 'White Indians' and relates how 'when the Moon-shiny nights come, they are all Life and Activity, running abroad, and into the Woods, skipping about like Wild-Bucks'. Among the Cuna, there is a particularly strong link between albinism and the moon cult (Keeler 1964:1-11).

In Greco-Roman literature, the location of the albino tribes mentioned in Isigonus, Pliny, Aulus Gellius, and Solinus, in the remote land of Albania (near modern Chechnya) may be related to the prevalence of the cult of the moon there. Strabo (11.4 [Albanians], especially 11.4.7 C503 [Selene cult]) refers to the cult of Selene among the Albanians in which a human sacrifice was performed annually. The victim was usually one who

36 (two narratives of Cepheus and Perseus respectively $-4^{\text {th }}$ century CE); Tzetzes Schol Lyc 836 (12 $2^{\text {th }}$ century); and First Vatican Mythographer 73 SRML 1.24.

40 For the myth of Andromeda as an account of the sacrifice of an albino, see Hilton (1998a:11-12). 
wandered the woods in a state of possession. Such a person would be arrested by the priest, looked after for a year, and then sacrificed by stabbing with a lance. Divinations were made on the basis of how his body fell to the ground $^{41}$.

Further evidence for the connection between the cult of Selene and albinism can be found in a fictitious narrative entitled Incredible things beyond Thule, by Diogenes, who wrote at some time during the early Roman Empire (cf. Stephens \& Winkler 1995:118-119). This author has his heroine, Derkyllis refer to people in Iberia, who could see in the dark but were blind by day (Photius Bibl 109b3) (Stephens \& Winkler 1995:123-124). Iberia is usually identified with Thracian Iberia in the Caucasus region, adjacent to Albania. Derkyllis goes on to describe how they fled from some Celts on horses that changed color (cf. Strabo 3.4.15), how the eyes of her companion and fellow-traveler, Astraeus, grew smaller and larger with the waxing and waning of the moon, and how this enabled him to reconcile two warring kings by proposing that they share power according to the phases of the moon (Stephens \& Winkler 1995:124). According to the paradoxographer, Apollonius, Eudoxus of Rhodes also mentions a Celtic tribe who could see by night but were blind by day (Giannini 1965). This Eudoxus may be the same author as Eudoxus of Cyzicus ( ${ }^{\text {rd }}$ century BCE), who had been sent by Ptolemy VIII to find a sea route to India and composed a number of accounts of his sea voyages (Strabo 2.3.4-5 [C98-C102]) ${ }^{42}$ (Cary \& Warmington 1929:90-91, 123-128). Alternatively, the information of Eudoxus of Rhodes may have been incorporated in the writings of Eudoxus of Cyzicus. In any case, the story ultimately goes back to the time of Aristotle, since Stephanus of Byzantium states in his Ethnica (s.v. Germara) that Aristotle has recorded the existence of a Celtic tribe, the Germara, who are blind by day, in his work $O n$ Marvels $^{43}$ (Billerbeck 2006:420-421).

41 This recalls the sacrifice of scapegoats in ancient religions (cf. Bremer 1983; Girard 1986).

42 For the text of Apollonius Mir 24, see Giannini (1965).

${ }^{43}$ There is also an account in Aristotle (HA 3.12.519a.5-19) of how animals belonging to the same species may have both white and black members, and how in one region there were two rivers that caused the rams who drank from them to produce white or black lambs depending on the river they had drunk from. 
The presence of Celts in Iberia in the Caucasus should not surprize, since in antiquity, Celtic tribes were found across a wide northerly region stretching from Galicia in the west to Galatia in Turkey and beyond (Powell [1958] 1985; Rankin [1987] 1996). The location of this tribe among the Celts may also not be accidental, since Celtic beliefs about reincarnation and immortality were sometimes considered Pythagorean (Diodorus Siculus 5.28. 6; Oldfather 1933:170-173), and Pythagoreanism plays a significant role in Diogenes' narrative. In his Life of Pythagoras (10-17), Porphyry provides further information about this episode in Diogenes' novel. According to him, Diogenes related how an itinerant Etruscan named Mnesarchus came across Astraeus as a baby, lying underneath a poplar tree and gazing at the sun without blinking. This baby was fed from the dew from the trees through a straw in its mouth. Reckoning that the infant was divine, Mnesarchus adopted the child, gave him the name Astraeus, and then entrusted him to Pythagoras, who studied 'the way his body moved and rested, and oversaw his education' (VP 13; Stephens \& Winkler 1995:134-135).

Astraeus is included in Hesiod's Theogony (375-382) as the son of Crio and Eurybia, who, together with Eos (Dawn), in turn begot the winds, Zephyr, Boreas, and Notus, as well as the star, Eosphorus (the morning star,

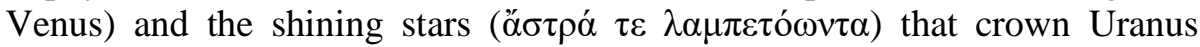
(West 1966). The brother of Astraeus was the Titan Perses who begot Hecate with Asteria (409) ${ }^{44}$ (Stephens \& Winkler 1995). This genealogy reinforces the connection between Astraeus and the heavenly bodies, which is strengthened also by the etymology of the name (Astraeus is derived from $\dot{\alpha} \sigma \tau \eta \dot{\eta}=$ star) and the reference in Aratus' Phaenomena 98-99, where Astraeus is described as 'the original father of the stars'45 (Rohde 1914:284).

The lunar sibyl plays an important role in the novel of Antonius Diogenes. In the course of the narrative, Deinias summarizes the story, to the exasperation of Photius: 'In their progress northwards they came close to the

44 However, an alternative tradition makes Perses the son of Perseus and Andromeda, and the progenitor of the Persian race (Kidd 1997:80).

45 These details recall the connection between albinos and the sun, moon, and stars in anthropology (see above) and the social authority that derives from this link. The feminine version of the name, Astraea, represents Justice in later mythology. Some have thought that Astraeus may be a double of Aristaeus, the heir of Pythagoras (cf. Iamblichus VP 265). 
moon, as to a very pure land, and there they saw what you would expect a person to see who had previously made up lies out of all proportion. Then how the Sibyl took the opportunity provided by Karmanes to prophecy again' (Stephens \& Winkler 1995:126). This recalls Plutarch's account (De Pyth Or 398c-d) of how the Delphic Sibyl claimed that after her death she would not cease prophesying but would become the face of the moon and that her body would be transformed into the grass growing on the earth and 'on this shall pasture the creatures reared for the holy sacrifice, and they shall acquire all manner of colours and forms and qualities upon their inward parts, from which shall come for men prognostications of the future' (Babbitt 1969:281).

There was great interest in the influence of the moon on human existence in antiquity. Xenocrates equated the moon with the nature of the daemones in his statement that 'there is a body of mixed nature which actually parallels the daemones, namely the moon' (Plutarch De Def Or 416c). Another writer, Aëtius (fr 15), talks of 'sublunary demons' (hyposelenoi daimones). Plutarch's dialogue On the Face in the Moon (De fac 937938af) discusses how these beings survive in such a harsh environment, since Ethiopians are burnt by the dry atmosphere in their region of earth ${ }^{46}$.

\section{Albinism and the Cult of Helios}

The anthropological literature cited above provides evidence that albinism was connected with the sun in traditional knowledge systems. In antiquity, a sun-god is found in a number of Indo-European societies (West 2007:190237). The Indo-European convention of Helios' course through the sky in a horse-drawn chariot or a boat may date to the middle of the second millennium. The dawn (Eos) was also treated as a goddess at this time, and the sun was said to have a daughter, who was associated with the sons of God, who were her suitors.

In Greece, Helios predates the Olympian gods and goddesses (West 2007). In Homer, he is all-seeing (Il 3.277; Od 11.109), the 'unwearying eye of heaven' and 'the mother of our eyes' (Ar Nub 285-286; Pind fr 44), and he is consequently invoked as a witness to oaths (Il 19.258). Some mythological characters are described as children of Helios, the progenerative power of

46 For a more extensive discussion of ancient ideas about the moon, see Hilton (2005). 


\title{
John L. Hilton
}

nature, and his wife, Perse or Perseis (also one of the names of the moongoddess Hecate [see above]), who could be identified with Persephone, but was also sometimes called Neaera. They had two sons, Aeetes and Phaethon (Kerényi 1951:194-196), and numerous daughters, including Lampetia and Phaethousa, who guarded the cattle of Helios on the island of Thrinacia in the Odyssey, Aegle or Phoebe ('moonlight'), Helia ('the female sun'), the Charites, Circe, Pasiphae ('shining for all'), and Medea (Kerényi 1951).

In the Odyssey, Circe lives close to the house and dancing-place of dawn and the risings of the sun (Od 12.3-4). In Apollonius of Rhodes' Argonautica, she is described as the daughter of Helios and the sister of Aeetes, the son of Helios with Perses (Od 3.309-311). Circe performs rituals of purification for Medea, Jason, and his followers. Circe herself is marked out by her 'appearance and her eyes' (Od 4.683-684) and she instantly recognizes Medea, her niece, from the brightness of her eyes (Apollonius Rhodios 4.725-729; Seaton [1912] 1967:342) ${ }^{47}$ :

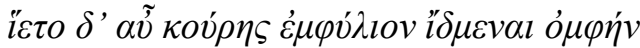

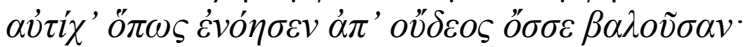

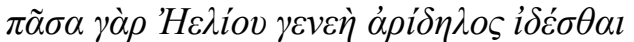 \\ $\tilde{\eta} \varepsilon v, \dot{\varepsilon} \pi \varepsilon \grave{\imath} \beta \lambda \varepsilon \varphi \alpha \dot{\rho} \rho \omega \dot{\alpha} \pi o \tau \eta \lambda o ́ \theta l \mu \alpha \rho \mu \alpha \rho v \gamma \tilde{\eta} \sigma l v$

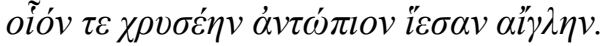

[T] he moment she saw Medeia raise her eyes from the ground, She was eager to hear her voice - a kinwoman's surely, For all the Sun's descendants were impossible to mistake,

Since from under their eyelids they darted a radiance

Far in front of them, a brightness like that of gold.

Medea's eyes have a magical power in the Argonautica: She puts the serpent who was guarding the fleece to sleep with the power of her gaze $(O d 4.145$ 147) and overcomes the bronze man, Talos with her vision (Od 4.1669-1672). The fear of catching the eye of Medea that the citizens of Colchis display ( $\mathrm{Od}$ $3.885-886$ ) may be due to their belief in the power of the 'evil eye'48.

47 The translation of Apollonius Rhodios is found in Green (1997:132).

48 Helen of Sparta too, while not explicitly named as the daughter of Helios, is associated with the sun. This is apparent from her association with the Dioscuri, 
Belief in astral deities is characteristic of early stages of Greek religion. Later, such beliefs were replaced by the cult of the Olympian gods. However, the evidence adduced above indicates that a belief in the influence of astral powers also continued in later times.

\section{Conclusion}

The above discussion of the evidence of albinism from the ancient Mediterranean world shows that attitudes towards the condition changed over time. Religious explanations were often advanced to explain the unusual births of albinos and their startlingly different appearance. Later, rationalizations of such births, such as the theory of maternal impression, in which the fetus was thought to have been affected by what the mother had been gazing on at the time of conception, were put forward to explain them. Conception at midday, when the sun was at the peak of its power, was held to be a causative factor. Moreover, from time to time, albinos were exposed at birth or 'made sacred' as the victims of human sacrifice in mythological accounts. Albinism was also consistently associated with astral cults of the sun, moon, and stars, especially in the Graeco-Roman culture. Later, however, particularly in the paradoxographical treatises, and as knowledge about the wider world developed they were viewed with greater realism, and were considered oddities, paradoxical figures who sometimes aroused contempt, as in the case of the anecdote concerning Aulus Gellius. All this is very different from the modern understanding of the condition as a genetic accident, but one that has similar consequences in terms of the social isolation of those who inherit these genes.

\section{References}

Agamben, G. 1998. Homo sacer: Sovereign power and bare life. HellerRoazen, D. (trans.). Stanford, CA: Stanford University Press.

Andree, R. 1889. Ethnographische Parallelen und Vergleiche. Classic Reprint Series. Leipzig: Von Veit Verlag.

Ardener, E.W. 1954. Some Ibo attitudes to skin pigmentation. Man 54: 7173.

her birth from a goose-egg, and the recurrent motif of the abduction of the sunmaiden in ancient mythology. For these associations, see West (2007:230-232). 
Avigad, N. \& Y. Yadin 1956. A Genesis apocryphon: A scroll from the wilderness of Judaea. Jerusalem: Magnes.

Babbitt, F.C. (ed. \& trans.) 1969. Plutarch: Moralia (351 C-438 E). London: Heinemann.

Baker, C. 2010. The myths surrounding people with albinism in South Africa and Zimbabwe. Journal of African Cultural Studies 22, 2: 169-181.

Baker, C. 2011. Enduring negativity: Representations of albinism in the novels of Didier Destremau, Patrick Grainville and Williams Sassine. Oxford: Peter Lang.

Berger, P. 1974. Some second thoughts on substantive V functionalist definitions of religion. Journal for the Scientific Study of Religion 13, 2: $125-133$.

Bigwood, J.M. 1989. Ctesias' Indica and Photius. Phoenix 43: 302-316.

Billerbeck, M. (ed.) 2006. Stephanus Byzantius: Ethnica. Vol. 1. Berlin: De Gruyter.

Bolton, J.D.P. 1962. Aristeas of Proconnesus. Oxford: Oxford University Press.

Bremer, J. 1983. Scapegoat rituals in Ancient Greece. Harvard T.H. Chan School of Public Health 87: 299-320.

Brocco, G. 2016. Albinism, stigma, subjectivity and global-local discourses in Tanzania. Anthropology and Medicine 23, 3: 229-243.

Bryceson, D.F., J.B. Jønsson, \& R. Sherrington 2010. Miners' magic: Artisanal mining, the albino fetish and murder in Tanzania. The Journal of Modern African Studies 48, 3: 353-382.

Bunte, B. 1875. Hygini Astronomica. Leipzig: Weigel.

Burkert, W. 1985. Greek religion: Archaic and classical. Raffan, J. (trans.). Oxford: Oxford University Press.

Cancik, H., H. Schneider, C.F. Salazar, \& D.E. Orton (eds.). 2002. Brill's new Pauly: Encyclopaedia of the ancient world: Antiquity. Leiden: Brill.

Cary, M. \& E.H. Warmington 1929. The ancient explorers. Penguin Classics. Harmondsworth: Penguin Books.

Charlesworth, J.H. 1983-1985. The Old Testament Pseudepigrapha. Vol. 1: Apocalyptic literature and testaments. New York: Doubleday.

Clarke, S. \& J. Beale 2018. Albinism and social marginalization. In Kromberg, J.G.R. \& P. Manga (eds.): Albinism in Africa. Cambridge, MA: Academic Press. 
Daston, L.J. \& K. Park 1998. Wonders and the order of nature, 1150-1750. New York: Zone Books.

De Heusch, L. 1985. Sacrifice in Africa. O’Brien, L. \& A. Morton (trans.). Manchester: Manchester University Press.

Dickie, M.W. 2001. Magic and magicians in the Greco-Roman world. London: Routledge.

Durkheim, É. 1915. The elementary forms of the religious life. Swain, J.W. (trans.). Mineola: Dover Publications.

Eby, C.H. \& H.D. Evjen 1962. The plague at Athens: A new oar in muddied waters. Journal of the History of Medicine and Allied Sciences 17, 2: 258-263.

Eliade, M. 1992. Mystic stories: The sacred and the profane. Cartianu, A. (trans.). Boulder: East European Monographs.

Fairbanks, A. (ed.) 1960. Philostratus: Imagines. Loeb Classical Library. Cambridge, MA: Harvard University Press.

Fairclough, H.R. (ed. \& trans.) [1926] 1966. Horace: Satires, epistles and ars poetica. Cambridge, MA: Heinemann.

Frazer, J.G. [1890] 2009. The golden bough: A study in magic and religion. Vol. 12 (1911-1915). London: Macmillan.

Froggatt, P. 1960. The legend of a white native race. Medical History 4, 3: 228-235.

Garland, R. 2010. The eye of the beholder: Deformity and disability in the Graeco-Roman world. London: Bristol Classical Press.

Geus, K. \& C.G. King 2018. Paradoxography. In Keyser, P.T. \& J. Scarborough (eds.): The Oxford Handbook of Science and Medicine in the classical world. Oxford: Oxford University Press.

Giannini, A. 1963. Studi Sulla Paradossografia Greca I: Instituto Lombardo Rend. Lett. 97. Milan: Istituto Lombardo di Scienze e Lettere.

Giannini, A. 1964. Studi Sulla Paradossografia Greca II: Acme. 17. Milan: Istituto Lombardo di Scienze e Lettere.

Giannini, A. (ed.) 1965. Apollonius: Historiae Mirabiles. Paradoxographorum Graecorum reliquiae. Milan: Istituto Editoriale Italiano.

Girard, R. 1986. The scapegoat. Freccero, Y. (trans.). Baltimore: John Hopkins University Press.

Graf, F. 2002. Theories of magic in antiquity. In Mirecki, P. \& M. Meyer (eds.): Magic and ritual in the ancient world. Leiden: Brill. 
Graves, R. 1948. The white goddess: A historical grammar of poetic myth. London: Faber \& Faber.

Green, P. (trans.) 1997. The Argonautika of Apollonios Rhodios. Berkeley: University of California Press.

Hansen, W. (trans.) 1996. Phlegon of Tralles: The book of marvels. Exeter: University of Exeter Press.

Hard, R. (trans.) 1997. Apollodorus: The Library of Greek Mythology. Oxford: Oxford University Press.

Harmon, A.M., K. Kilburn, \& M.D. Macleod (eds. \& trans.) 1961. Lucian. Loeb Classical Library. London: Harvard University Press.

Hilton, J.L. 1998a. A commentary on books 3 and 4 of the Ethiopian story of Heliodorus. PhD thesis, Department of Classics, University of Natal, Durban.

Hilton, J.L. 1998b. An Ethiopian paradox: Heliodorus, Aithiopika 4.8. Cambridge Philological Society (Supplementary Volume) 21: 79-92.

Hilton, J.L. 2005. Lucian and the great moon hoax of 1835. Akroterion 50: 87-107.

Hopper, J.M.H. 1992. An arenavirus and the plague of Athens. Journal of the Royal Society of Medicine 85: 350-351.

Hornblower, S., A. Spawforth, \& E. Eidinow (eds.) 2012. The Oxford Classical Dictionary. $4^{\text {th }}$ ed. Oxford: Oxford University Press.

Imafidon, E. 2019. African philosophy and the otherness of albinism: White skin, black race. Routledge Studies in African Philosophy 1. Abingdon: Routledge.

Imperato, P.J. \& G.H. Imperato 2008. Twins, hermaphrodites, and an androgynous albino deity: Twins and sculpted twin figures among the Bamana and Maninka of Mali. African Arts 41, 1: 40-49.

Jones, C.P. (trans.) 2005. Apollonius of Tyana. Vol. 1. Cambridge, MA: Harvard University Press.

Keeler, C.E. 1964. The incidence of Cuna moon-child albinos. Journal of Heredity 55, 3: 115-118.

Kerényi, C. 1951. The gods of the Greeks. Cameron, N. (trans.). London: Thames \& Hudson.

Kerényi, K. [1927] 1962. Die Griechisch-Orientalische Romanliteratur in religions-geschichtlicher Beleuchtung. Darmstadt: Wissenschaftliche Buchgesellschaft. 
Kerr, R. \& J.G.R. Kromberg 2018. Genetic testing, postnatal, and prenatal diagnosis for albinism. In Kromberg, J.G.R. \& P. Manga (eds.): Albinism in Africa. Cambridge, MA: Academic Press.

Kidd, D. (ed.) 1997. Aratus: Phaenomena. Cambridge: Cambridge University Press.

Kirkwood, B.J. 2009. Albinism and its implications with vision. Insight - the Journal of the American Society of Ophthalmic Registered Nurses 34, 2: 13-16.

Knibb, M.A. \& E. Ullendorff 1978. The Ethiopic book of Enoch I-II. Oxford: Clarendon Press.

Krappe, A.H. 1944. Albinos and albinism in Iranian tradition. Folklore 55, 4: 170-174.

Kroll, W. (ed.) [1908] 1973. Anthologiarum libri ix: Vettii Valentis anthologiarum libri. Berlin: Weidmann.

Kromberg, J. 1992. Albinism in the South African Negro IV: Attitudes and the death myth. Birth Defects Original Article Series 28, 1: 159-166.

Kromberg, J.G.R. 1987. Albinism in Southern Africa: Why so common in blacks. South African Journal of Science 83: 68.

Kromberg, J.G.R. 2018a. Epidemiology of albinism. In Kromberg, J.G.R. \&

P. Manga (eds.): Albinism in Africa. Cambridge, MA: Academic Press.

Kromberg, J.G.R. 2018b. Introduction and historical background. In Kromberg, J.G.R. \& P. Manga (eds.): Albinism in Africa. Cambridge, MA: Academic Press.

Kromberg, J.G.R. 2018c. Psychosocial and cultural aspects of albinism. In Kromberg, J.G.R. \& P. Manga (eds.): Albinism in Africa. Cambridge, MA: Academic Press.

Kromberg, J.G.R. \& T. Jenkins 1984. Albinism in the South African Negro

III: Genetic counselling issues. Journal of Biosocial Science 16, 1: 99-108.

Kromberg, J.G.R. \& P. Manga (eds.) 2018. Albinism in Africa. Cambridge, MA: Academic Press.

Kromberg, J.G.R., M.E. Zwane, \& T. Jenkins 1987. The response of black mothers to the birth of an albino infant. The American Journal of Diseases of Children 141, 8: 911-916. 
Lenfant, D. (ed.) 2004. Ctésias: La Perse, L'inde, Autres Fragments. Collection des universités de France série grecque 435. Paris: Les Belles Lettres.

Lewis, R.A. 2015. Ocular albinism, X-Linked. NCBI Resources. November 19, 2015. Available at: https://www.ncbi.nlm.nih.gov/books/NBK 1343/. (Accessed on April 8, 2020.)

Liddle, H.G. \& R. Scott 1968. A Greek-English lexicon. Jones, H.S. (rev.). New ed. Oxford: Clarendon.

Little, R. 1995. Nègres Blancs: Représentations de L'autre Autre: Essai. Paris: L'Harmattan.

Littman, R.J. \& M.L. Littman 1969. The Athenian plague: Smallpox. Transactions of the American Philological Association 100: 261-275. Malinowski, B. 1948. Magic, science and religion and other essays. Redfield, R. (ed.). Boston, MA: Beacon Press.

Malouf, D. 1993. Remembering Babylon. London: Vintage.

Mauss, M. 1972. A general theory of magic. Brain, R. (trans.). London: Routledge.

Melville, H. 1851. Moby-Dick or the white whale. Boston, MA: The St. Botolph Society.

Milik, J.T. 1976. The books of Enoch: Aramaic fragments of Qumran cave 4. Oxford: Clarendon Press.

Mommsen, T. (ed.) [1895] 1958. Solinus, C. Julius: Collectanea Rerum Memorabilium. Berolini: Weidmann.

Moreno, L.A.G. 1992. Paradoxography and political ideas in Plutarch's Life of Sertorius. In Stadter, P.A. (ed.): Plutarch and the historical tradition. London: Routledge.

Morens, D.M. \& R.J. Littman 1992. Epidemiology of the plague of Athens. Transactions of the American Philological Association 122: 271-304.

Nobbe, K.F.A. \& A. Diller [1843-1845] 1966. Claudii Ptolemaei Geographia. Vol. 1. Hildesheim: G. Olms.

Olby, R.C. 1994. The path of the double helix: The discovery of DNA. Dover Books on Biology, Psychology, and Medicine. New York: Dover Publications.

Oldfather, C.H. (ed. \& trans.) 1933. Diodorus of Sicily. Loeb Classical Library. Cambridge, MA: Harvard University Press.

Otto, R. 1917. Das Heilige: Über das Irrationele in der Idee des Göttlichen und sein Verhältnis zum Rationalen. Gotha: Leopold Klotz. 
Papagrigorakis, M.J. 2006. DNA examination of ancient dental pulp incriminates typhoid fever as a probable cause of the plague of Athens. International Society for Infectious Diseases 10: 206-214.

Pearson, K., E. Nettleship, \& C.H. Usher 1911-1913. A monograph on albinism in man. Draper's Company Research Memoirs Biometric Series VI-IX. London: Dulau.

Perrin, B. (ed. \& trans.) [1919] 1968. Plutarch Lives. Vol. 8. Loeb Classical Library. Cambridge: Harvard University Press.

Pirie, J.W. \& W.M. Lindsay (eds.) 1930. Glossaria Latina Iussu Academiae Britannicae Edita. Vol. 4: Placidius Lactantius and Sextus Pompeius Festus. Paris: Les Belles Lettres.

Powell, T.G.E. [1958] 1985. The Celts. London: Thames \& Hudson.

Rackham, H., W.H.S. Jones, \& D.E. Eichholz (ed. \& trans.) 1938. Pliny: Natural History. The Loeb Classical Library. London: Heinemann.

Rankin, H.D. [1987] 1996. Celts and the classical world. London: Routledge.

Reeve, M.D. 1989. Conceptions. Proceeding of the Cambridge Philological Society 215: 81-112.

Rennie, B.S. (ed.) 2006. Mircea Eliade: A critical reader. Critical Categories in the Study of Religion. London: Equinox.

Rohde, E. 1914. Der griechische Roman und seine Vorläufer. Darmstadt: Georg Olms.

Rolfe, J.C. 1927. The Attic Nights of Aulus Gellius. The Loeb Classical Library. London: Heinemann.

Romer, F.E. (trans.) 1998. Pomponius Mela: Description of the world. Ann Arbor: University of Michigan Press.

Rommel, H. 1923. Die naturwissenschaftlich-paradoxographischen Exkurse bei Philostratos, Heliodoros und Achilleus Tatios. Stuttgart: Kohlhammer Verlag.

Schürer, E., G. Vermes, F. Millar, \& M. Goodman 1986. The history of the Jewish people in the age of Jesus Christ. Vol. 3. Edinburgh: Cambridge University Press.

Seaton, R.C. (ed. \& tr.) [1912] 1967. Apollonius Rhodius: The Argonautica. Cambridge, MA: Heinemann.

Sebestyén, G. 1993. A man too white. Mitchell, M. (trans.). Riverside: Ariadne.

Simpson, J.A. \& E.S.C. Weiner 1989. The Oxford English Dictionary. Oxford: Clarendon Press. 
Snowden, F.M. 1970. Blacks in antiquity: Ethiopians in the Greco-Roman experience. Cambridge, MA: Harvard University Press.

Snowden, F.M. 1983. Before color prejudice: The ancient view of blacks. Cambridge, MA: Harvard University Press.

Sorsby, A. 1974. Noah: An albino. In Sorsby, A. (ed.): Tenements of clay: An anthology of medical biographical essays. New York: Julian Friedmann.

Spritz, R.A. 2013. Albinism. In Maloy, S. \& K. Hughes (eds.): Brenner's Encyclopaedia of genetics. Cambridge, MA: Elsevier.

Stephens, S. \& J.J. Winkler (eds.) 1995. Ancient Greek novels: The fragments. Introduction, text, translation and commentary. Princeton: Princeton University Press.

Stout, D.B. 1946. Further notes on albinism among the San Blas Cuna, Panama. American Journal of Physical Anthropology 4: 483-490.

Van der Leeuw, G. 1986. Religion in essence and manifestation. Turner, J.E. (trans.). Princeton: Princeton University Press.

Vermes, G. 2004. The complete Dead Sea Scrolls in English. London: Penguin Books.

Wafer, L. 1934. A new voyage and description of the Isthmus of America (1699). Elliot Joyce, L.E. (ed.). Oxford: Hakluyt Society.

Warde Fowler, W. 1911. The original meaning of the word sacer. The Journal of Roman Studies 1: 57-63.

West, M.L. (ed.) 1966. Hesiod: Theogony. Oxford: Oxford University Press.

West, M.L. 2007. Indo-European poetry and myth. Oxford: Oxford University Press.

Woolf, C.M. \& R.B. Grant 1962. Albinism among the Hopi Indians in Arizona. American Journal of Human Genetics 14: 391-400.

Prof John Laurence Hilton University of the Free State jlhilton@webafrica.org.za 